Jurnal Ekonomi dan Perbankan Syariah

Vol. 6. No.1, April, 2018: 63-89, ISSN (cet): 2355-1755 | ISSN (online): 2579-6437

\title{
FAKTOR-FAKTOR YANG MEMPENGARUHI RETURN BAGI HASIL DEPOSITO MUDHARABAH (Studi Empiris Pada Bank Umum Syariah di Indonesia Tahun 2012-2016)
}

\author{
Khairul Umuri, Endang Ahmad Yani dan \\ Abdi Triyanto ${ }^{1,4}$
}

\author{
${ }^{1,3}$ Afiliasi: Sekolah Tinggi Ekonomi Islam SEBI. \\ Email:khairulumuri13@gmail.com,ahyani2009@gmail.com,,abdi.triyanto@gmail.com
}

\begin{abstract}
This research aims to test the influence of Financing to Deposit Ratio (FDR), Non-Performing Financing (NPF), and operating income against operating expenses return for the results on the Mudharabah deposit a public Bank Syariah 2012-2016 period. The object of this research is full-fledged Islamic Bank in Indonesia. Sampling is done by purposive sampling technique so that the retrieved 9 samples of full-fledged Islamic Banks during period 2012-2016. Methods of analysis used in this study was multiple linear regression using panel data that help by using Eviews9. The results of this study indicate that simultaneously independent variable has no effect significantly to the rare of profit sharing deposito mudharaba in islamic bank. While partially, FDR and the NPF has no effect significantly to the rare of profit sharing deposito mudharaba in islamic bank, and $B O P O$ has positive significantly effect to the rare of profit sharing deposito mudharaba in islamic bank.
\end{abstract}

Keywords: Financing to Deposit Ratio, Non Performing Financing, Islamic Bank, Profit Sharing, Deposito Mudharaba

\section{PENDAHULUAN}

Pada tahun 1997, Asia Tenggara mengalami krisis moneter yang cukup parah sehingga mampu mengubah perekonomian Indonesia menjadi terpuruk. Salah satu permasalahan yang muncul saat itu adalah bank menghadapi negatif spread yakni suku bunga tabungan lebih besar dari pada suku bunga pinjaman, hal ini menyebabkan bank sulit memperoleh keuntungan (Yuliani, 2011). Krisis finansial kembali melanda berbagai negara di dunia pada tahun 2008. Krisis financial yang ditandai dengan salah satu bank terbesar Perancis BNP Paribas mengumumkan pembekuan beberapa sekuritasnya terkait dengan kredit perumahan beresiko tinggi Amerika Serikat (subprime mortgage). Di penghujung triwulan III-2008, intensitas krisis semakin membesar seiring dengan bangkrutnya bank investasi terbesar Amerika Serikat Lehman Brothers, yang diikuti oleh kesulitan keuangan yang semakin parah di seluruh lembaga keuangan berskala besar di Amerika Serikat, Eropa, dan Jepang (Tjahjono, Ari, Yanuarti, Hermansyah, \& Savitri, 2009).

Melihat fakta tersebut, rasanya mustahil bagi perbankan bertahan ditengah krisis yang sangat sulit. Namun menariknya adalah bank syariah berhasil membuktikan diri sebagai lembaga keuangan yang mampu bertahan ditengahtengah krisis yang melanda dunia. International Monetary Fund (IMF) 
memperkirakan terjadinya perlambatan pertumbuhan ekonomi dunia dari 3,9\% pada 2008 menjadi 2,2\% pada tahun 2009. Namun, kinerja pertumbuhan pembiayaan bank syariah di Indonesia pada saat itu tetap tinggi sampai posisi Februari 2009 dengan kinerja pembiayaan yang baik (Non Performing Financing di bawah 5\%). Penyaluran pembiayaan oleh perbankan syariah per Februari 2009 ssecara konsisten terus mengalami peningkatan dengan pertumbuhan sebesar 33,3\% pada Februari 2008 menjadi 47,3\% pada Februari 2009 (Wibowo \& Syaichu, 2013).

Meskipun begitu, pangsa pasar (market share) Perbankan Syariah di Indonesia masih berkisar 5\% dari total aset perbankan nasional. Deposan perbankan syariah hanya tiga juta orang, jika kita bandingkan dengan potensi deposan yang melebihi 100 juta orang di Indonesia. Dengan kondisi ini kita bisa melihat bahwa masih banyak Muslim di Indonesia yang belum berinteraksi dengan perbankan Syariah (M. Arif, 2011). Padahal, sebagai negara dengan penduduk muslim terbesar, sudah selayaknya Indonesia menjadi pelopor dan kiblat pengembangan keuangan syariah di dunia. Hal ini bukanlah impian semata, mengingat Indonesia memiliki potensi yang sangat besar untuk menjadi Global Player keuangan syariah (Alamsyah, 2015). Pada tahun 2016, Indonesia menempati urutan ke-7 sebagai negara yang memiliki potensi dan kondusifitas dalam pengembangan industri keuangan syariah di dunia (IFCI, 2016).

Dalam 5 tahun terakhir (2007-2011), industri perbankan syariah mampu menunjukkan akselerasi pertumbuhan yang sangat signifikan dengan rata-rata sebesar $40,2 \%$ pertahun. Sementara rata-rata pertumbuhan perbankan nasional hanya $16,7 \%$ pertahun. Oleh karena itu, industri perbankan syariah dijuluki sebagai 'the fastest growing industry' (Alamsyah, 2015). Sementara itu peningkatan peranan industri keuangan syariah Indonesia menuju global player juga tergambar dari meningkatnya rangking total aset keuangan syariah Indonesia dari urutan ke-13 pada tahun 2010 naik menjadi urutan ke-9 dengan nilai aset sebesar \$21,044 miliar pada tahun 2015 (The Banker, 2015).

Sebagai industri yang bergerak di sektor jasa perbankan, bank syariah membutuhkan sumber dana untuk memenuhi kebutuhan permodalan dan kebutuhan pembiayaan dalam fungsinya sebagai lembaga intermediasi (Novianto \& Hadiwidjojo, 2013). Pada tahun 2016, sumber dana perbankan syariah yang terbesar adalah dari Bank Umum Syariah (BUS) dan Unit Usaha Syariah (UUS) yang berasal dari Dana Pihak Ketiga sebesar Rp. 279,335 triliun. Komposisi terbesar berasal dari dana produk deposito Mudharabah sebesar Rp. 166,174 triliun. Sementara total DPK pada Bank Pembiayaan Rakyat Syariah (BPRS) pada tahun 2016 hanya mencapai Rp. 5,823 triliun, sedangkan dana yang berasal dari deposito sebesar Rp. 3,662 triliun (OJK, 2016).

Hal ini dibuktikan dengan data yang dilaporkan dalam Statistik Perbankan Syariah pada tahun 2011-2015, jumlah deposito Mudharabah yang di himpun oleh perbankan syariah mengalami peningkatan dari Rp 70.80 triliun menjadi Rp 129.8 triliun. Dalam rentang waktu lima tahun, jumlah deposito Mudharabah telah tumbuh sebesar 207,48 persen. Selain itu, dilihat dari proporsinya terhadap total DPK, proporsi deposito Mudharabah selama periode tahun 2011-2015 juga 
Jurnal Ekonomi dan Perbankan Syariah

Vol. 6. No.1, April 2018: 63-89, ISSN (cet): 2355-1755 | ISSN (online): 2579-

6437

| 63

mengalami peningkatan dari 57,9 persen menjadi 62,3 persen (Rahayu \& Pranowo, 2012).

Walaupun total dana deposito Perbankan Syariah terus mengalami kenaikan, namun market share bank syariah masih tertinggal jauh jika dibandingkan dengan market share bank konvensional. Oleh karena itu, bank syariah harus terus mengembangkan potensinya untuk dapat meningkatkan market share. Menurut Syibly (2008) pengembangan nasabah pada bank syariah lebih berpotensi terhadap floating market. Dalam penelitian Karim \& Affif (2006) mengatakan bahwa floating market adalah nasabah yang lebih mengedepankan alasan rasional dalam memilih jasa perbankan yaitu dalam hal kenyamanan dan keuntungan yang bisa didapatkan.

Dengan demikian kemampuan manajemen untuk menjalankan fungsinya sebagai penyimpan harta, pengusaha dan pengelola investasi yang baik (professional investment manager) akan sangat menentukan kualitas usaha bank syariah sebagai lembaga intermediary dan kemampuannya menghasilkan keuntungan (Umiyati \& Syarif, 2014). Return bagi hasil merupakan salah satu faktor yang menjadi pertimbangan bagi nasabah dalam menginvestasikan dananya di perbankan syariah, untuk itu menjadi cukup penting bagi bank syariah untuk tetap menjaga kualitas tingkat bagi hasil yang diberikan kepada nasabahnya (Isna \& Sunaryo, 2012).

Sekalipun terdapat berbagai faktor non-ekonomis yang sangat mempengaruhi interaksi masyarakat dengan dunia perbankan, namun dalam keputusan memilih jasa perbankan tetap saja pertimbangan rasional (rational choice) sangat menentukan (Rivai et al., 2006). Oleh karena itu, bank syariah harus terus meningkatkan besaran bagi hasil. Apabila besaran bagi hasil deposito di bank syariah rendah, maka nasabah akan cenderung memindahkan dananya ke bank lain yang memiliki keuntungan yang lebih besar (Natalia, Dzulkirom, \& Rahayu, 2014).

Grafik 1. Tingkat Return Bank Syariah dan Konvensional

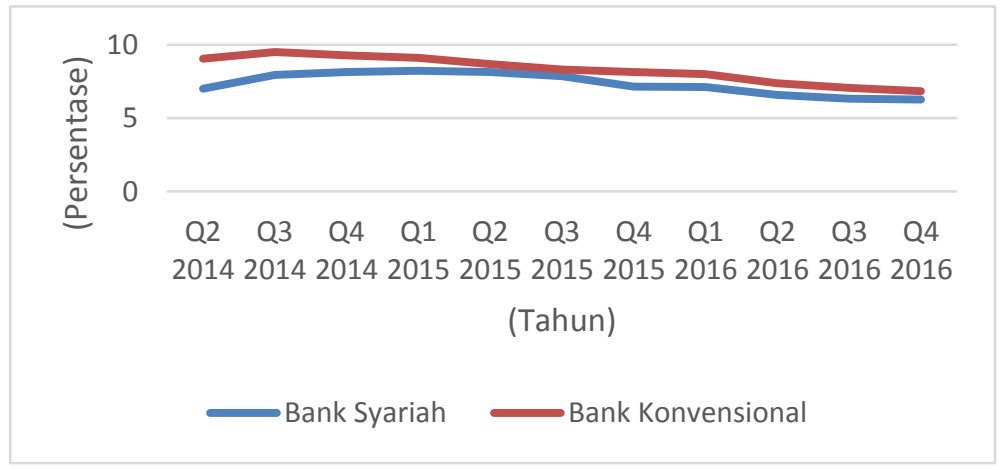

Sumber : Statistik Perbankan Syariah, 2016

Berdasarkan grafik di atas, dapat dilihat bahwa return bagi hasil yang dihasilkan oleh bank syariah lebih rendah dibandingkan dengan bunga deposito 
pada bank konvensional. Selain itu, return bagi hasil deposito bank syariah juga lebih fluktuatif dibanding suku bunga deposito bank konvensional yang cenderung lebih flat. Hal ini tentu akan menjadi pertimbangan bagi nasabah dalam memilih bank untuk menginvestasikan dananya.

Dengan demikian, bank syariah dihadapkan pada tantangan selain mengedepankan aspek religiusitas atau aspek syariah tetapi juga harus mampu mengedepankan produk-produk yang ramah pasar untuk dapat bersaing dengan bank konvensional. Bank syariah tidak bisa hanya mengandalkan nasabah sharia committed market, namun bank syariah juga harus mampu menarik nasabah floating market yang mengedepankan rasionalitas dalam memilih jasa perbankan. Berdasarkan latar belakang di atas, maka penulis tertarik untuk melakukan penelitian tentang return bagi hasil pada produk deposito mduharabah di bank syariah dengan mengambil judul penelitian "Faktor-faktor yang Mempengaruhi Return Bagi Hasil Deposito Mudharabah (Studi Empiris Pada Bank Umum Syariah di Indonesia Tahun 2012-2016)".

\section{LANDASAN TEORI}

\subsection{Pengertian Bank Syariah}

Ismail (2017, hlm. 20) mendefenisikan bahwa Bank Syariah merupakan bank yang dalam kegiatannya mengacsu pada hukum Islam, dan dalam kegiatannya tidak membebankan bunga, maupun tidak membayar bunga kepada nasabah. Imbalan yang diterima oleh bank syariah maupun yang dibayarkan kepada nasabah tergantung dari akad dan perjanjian antara nasabah dan bank. Perjanjian tersebut didasarkan pada hukum syariah, baik perjanjian yang dilakukan bank dengan nasabah dalam menghimpun dana, maupun penyalurannya. Perjanjian (akad) yang terdapat di perbankan syariah harus tunduk pada syarat dan rukun akad tersebut sebagimana diatur dalam syariah Islam.

Dalam Undang-undang Nomor 21 Tahun 2008 Tentang Perbankan Syariah yang dimaksud dengan : (Indonesia, 2008)

1. Perbankan Syariah adalah segala sesuatu yang menyangkut tentang Bank Syariah dan Unit Usaha Syariah, mencakup kelembagaan, kegiatan usaha, serta cara dan proses dalam melaksanakan kegiatan usahanya.

2. Bank Syariah adalah Bank yang menjalankan kegiatan usahanya berdasarkan Prinsip Syariah dan menurut jenisnya terdiri atas Bank Umum Syariah dan Bank Pembiayaan Rakyat Syariah.

3. Bank Umum Syariah adalah Bank Syariah yang dalam kegiatannya memberikan jasa dalam lalu lintas pembayaran.

\subsection{Pengertian Deposito}

Deposito adalah bentuk simpanan nasabah yang mempunyai jumlah minimal tertentu, jangka waktu terentu, dan bagi hasilnya lebih tinggi daripada tabungan. Nasabah membuka deposito dengan jumlah minimal tertentu dengan jangka waktu yang telah disepakati, sehingga nasabah tidak bisa mencairkan dananya sebelum jatuh tempo. Produk penghimpunan dana ini biasanya dipilih 
Jurnal Ekonomi dan Perbankan Syariah

Vol. 6. No.1, April 2018: 63-89, ISSN (cet): 2355-1755 | ISSN (online): 2579-

6437

\section{| 65}

oleh nasabah yang memiliki kelebihan dana, sehingga selain bertujuan untuk menyimpan dananya, juga bertujuan sebagai sarana untuk berinvestasi (Arif, 2010, hlm. 35).

\subsection{Pengertian Mudharabah}

Mudharabah berasal dari kata dharb, berarti memukul atau berjalan. Pengertian memukul atau berjalan ini lebih tepatnya adalah proses seseorang memukul kakinya dalam menjalankan usaha (Antonio, 2003, hlm. 95). Menurut Ismail (2010), al-Mudharabah adalah akad perjanjian antara dua pihak atau lebih dimana salah satu pihak sebagai pemilik modal yang menempatkan modalnya sebesar $100 \%$. Pemilik modal ini disebut shahibul maal, sedangkan pihak lainnya yang bertugas mengelola dana tersebut disebut dengan mudharib.

\subsection{Pengertian Bagi Hasil}

Prinsip bagi hasil (profit sharing) merupakan karakteristik umum dan landasan dasar bagi operasional bank syariah secara keseluruhan. Secara syariah, prinsipnya berdasarkan kaidah al-Mudharabah. Sistem bagi hasil merupakan suatu sistem yang meliputi tata cara pembagian hasil usaha antra penyedia dana dengan pengelola dana. Pembagian hasil usaha ini dapat terjadi antara bank dengan penyimpan dana, maupun dengan nasabah penerima dana. Bentuk produk pada sistem bagi hasil ini menggunakan prinsip Mudharabah dan musyarakah. Prinsip Mudharabah dapat digunakan sebagaio dasar baik untuk produk pendanaan maupun pembiayaan, sedangkan musyarakah lebih banyak untuk pembiayaan (Antonio, 2003, hlm. 137).

\subsection{Financing to Deposit Ratio (FDR)}

FDR (Financing to Deposit Ratio) adalah perbandingan antara pembiayaan yang diberikan oleh bank dengan dana pihak ketiga (DPK) yang berhasil dikerahkan oleh bank. FDR tersebut menyatakan seberapa jauh kemampuan bank dalam dalam membayar kembali penarikan dana yang dilakukan deposan dengan mengandalkan kredit yang diberikan sebagai sumber likuiditasnya. Dengan kata lain, seberapa jauh pemberian kredit kepada nasabah kredit dapat mengimbangi kewajiban bank untuk segera memenuhi permintaan deposan yang ingin menarik kembali uangnya yang telah digunakan oleh bank untuk memberikan kredit (Rahmawaty \& Yudina, 2015)

Semakin tinggi rasio Financing to Deposit Ratio (FDR) mengindikasikan tingkat pembiayaan yang tinggi dan ini berdampak pada meningkatnya return yang akan dihasilkan dari pembiayaan. Hal tersebut secara otomatis akan meningkatkan tingkat bagi hasil (Nofianti, Badina, \& Erlangga, 2015). Rasio ini merupakan indikator kerawanan dan kemampuan dari suatu bank. Sebagian praktisi perbankan menyepakati bahwa batas aman dari FDR suatu bank adalah sekitar $80 \%$. Namun, batas toleransi antara $85 \%$ dan $100 \%$. Sedangkan berdasarkan ketentuan yang tertuang dalam Surat Edaran Bank Indonesia No 26/5/BPPP tanggal 29 Mei 1993, besarnya FDR ditetapkan oleh Bank Indonesia tidak boleh melebihi $110 \%$. Dengan ketentuan ini berarti bank boleh memberikan 
66 | Khairul Umuri: Faktor-Faktor Yang Mempengaruhi Return Bagi Hasil Deposito Mudharabah (Studi Empiris Pada Bank Umum Syariah di Indonesia Tahun 2012-2016)

kredit atau pembiayaan melebihi jumlah dana pihak ketiga asalkan tidak melebihi $110 \%$.

\subsection{Non Performing Financing (NPF)}

Non Performing Financing (NPF) adalah perbandingan antara total pembiayaan bermasalah dengan total pembiayaan yang di berikan kepada debitur. Non Performing Financing (NPF) menunjukkan seberapa besar kolektibilitas bank dalam mengumpulkan kembali pembiayaan yang telah disalurkan. Jika pembiayaan bermasalah melampaui batas, maka akan menjadi masalah serius yang akan mengganggu profitabilitas bank syariah yang berujung pada berhentinya operasional. Bank Indonesia menetapkan NPF Gross sebesar 5\% sebagai angka toleransi bagi kesehatan suatu bank (Akbar, 2016). NPF mencerminkan risiko pembiayaan, semakin tinggi rasio ini, menunjukkan kualitas pembiayaan bank syariah semakin buruk. Pengelolaan pembiayaan sangat diperlukan oleh bank, mengingat fungsi pembiayaan sebagai penyumbang pendapatan terbesar bagi bank syariah. Tingkat kesehatan pembiayaan (NPF) ikut mempengaruhi pencapaian laba bank (Wibowo \& Syaichu, 2013).

Setiap bank tidak ada yang mengharapkan terjadinya Non Performing Financing, namun dalam perjalanan bisnisnya bank syariah tidak bisa lepas dari risiko-risiko yang tidak dapat diprediksi sejak awal. Perkembangan pemberian pembiayaan yang paling tidak menggembirakan bagi pihak bank adalah ketika pembiayaan yang diberikan ternyata menjadi bermasalah. Hal ini terutama disebabkan oleh kegagalan pihak debitur memenuhi kewajibannya untuk membayar angsuran (cicilan) pokok pembiayaan beserta bagi hasil yang telah disepakati oleh kedua belah pihak dalam perjanjian pembiayaan. NPF merupakan situasi dimana persetujuan pengembalian kredit mengalami risiko kegagalan, bahkan menunjukkan kepada bank akan mengalami risiko kegagalan.

\subsection{Biaya Operasional Pendapatan Operasional (BOPO)}

Biaya Operasional Pendapatan Operasional adalah raiso perbandingan antara biaya operasional dan pendapatan operasional. Rasio biaya operasi digunakan untuk mengukur tingkat dan distribusi biaya bank dalam melakukan kegiatan operasinya. Karena kegiatan utama bank pada prinsipnya adalah bertindak sebagai perantara yaitu menghimpun dana dan menyalurkan dana. Semakin rendah BOPO berarti semakin efisien bank tersebut dalam mengendalikan biaya operasionalnya, dengan adanya efisiensi biaya maka keuntungan yang diperoleh bank akan semakin besar (Wibowo \& Syaichu, 2013)

BOPO yaitu, rasio perbandingan antara Biaya Operasional dengan Pendapatan Operasional, semakin rendah tingkat rasio BOPO berarti semakin baik kinerja manajemen bank tersebut, karena lebih efisien dalam menggunakan sumber dana yang ada di perusahaan Besarnya rasio BOPO yang dapat ditolerir oleh perbankan di Indonesia adalah sebesar 93,52\%, hal ini sejalan dengan ketentuan yang dikeluarkan oleh Bank Indonesia. Dari rasio ini dapat diketahui tingkat efisiensi kinerja manajemen suatu bank, jika angka rasio menunjukkan angka diatas $90 \%$ dan mendekati $100 \%$ ini berarti bahwa kinerja bank tersebut menunjukkan tingkat efisiensi yang sangat rendah. Tetapi jika rasio ini rendah, 
Jurnal Ekonomi dan Perbankan Syariah

Vol. 6. No.1, April 2018: 63-89, ISSN (cet): 2355-1755 | ISSN (online): 2579-

6437

| 67

misalnya mendekati $75 \%$ ini berarti kinerja bank yang bersangkutan menunjukkan tingkat efisiensi yang tinggi (Rahayu \& Bustaman, 2016).

\subsection{Penelitian Terdahulu}

Beberapa penelitian sudah dilakukan mengenai faktor-faktor yang mempengaruhi return bagi hasil deposito Mudharabah pada bank syariah, diantaranya penelitian yang dilakukan oleh Isna dan Sunaryo (2012) menggunakan Return on Aset, BOPO dan Suku Bunga sebagai variabel independen yang dianggap mempengaruhi tingkat bagi hasil deposito Mudharabah. Hasil penelitiannya menunjukkan bahwa ROA, BOPO dan Suku Bunga secara simultan memiliki pengaruh yang signifikan terhadap tingkat bagi hasil deposito Mudharabah. Sementara itu secara parsial ROA memiliki pengaruh negatif signifikan terhadap tingkat bagi hasil, Suku Bunga berpengaruh positif signifikan terhadap tingkat bagi hasil, sedangkan BOPO tidak memiliki pengaruh yang signifikan terhadap tingkat bagi hasil deposito Mudharabah bank syariah.

Penelitian lainnya yang dilakukan oleh Arfiani dan Mulazid (2017) menggunakan FDR, NPF, dan Inflasi debagai variabel independen yang mempengaruhi tingkat bagi hasil deposito Mudharabah. secara simultan, ketiga variabel FDR, NPF, dan Inflasi berpengaruh terhadap tingkat bagi hasil deposito Mudharabah. Secara parsial, FDR dan NPF mempengaruhi tingkat bagi hasil deposito Mudharabah bank umum syariah.

\section{METODOLOGI PENELITIAN}

\subsection{Jenis Penelitian}

Jenis penelitian ini menggunakan pendekatan kuantitatif. yaitu penelitian yang menggunakan data-data berupa angka yang dikumpulkan dari fakta dan sifat objek penelitian secara sistematis. Sedangkan berdasarkan tingkat ekplanasinya, penelitian ini termasuk dalam jenis penelitian asosiatif (korelasional). Penelitian asosiatif bertujuan untuk mengetahui hubungan antara pengaruh variabel independen dengan variabel dependen (Sanusi, 2014, hlm. 115).

\subsection{Populasi dan Sampel}

Populasi yang digunakan dalam penelitian ini yaitu semua Bank Syariah yang beroperasi di Indonesia sampai tahun 2017. Sedangkan sampel dalam penelitian ini dipilih menggunakan teknik purposive sampling, yaitu cara pengambilan sampel yang didasarkan pertimbangan-pertimbangan (kriteriakriteria) tertentu (Sanusi, 2016, hlm. 95). Berdasarkan teknik purposive sampling yang telah dilakukan, maka didapatlah 9 Bank Syariah yang dijadikan sampel penelitian, yaitu BNI Syariah, BRI Syariah, Bank Mega Syariah, Bank Muamalat Indonesia, Bank Panin Syariah, Bank Syariah Bukopin, Bank Syariah Mandiri, Bank BJB Syariah dan Maybank Syariah Indonesia.

\subsection{Jenis dan Sumber Data}


Jenis data yang dipakai dalam penelitian ini adalah data sekunder, yaitu data yang diperoleh secara tidak langsung dari pihak lain melalui media perantara dari berbagai sumber yang tersedia. Sedangkan sumber data yang digunakan dalam penelitian ini adalah bersumber dari laporan keuangan Bank Umum Syariah yang dipublikasikan dalam masing-masing websitenya selama priode 2011-2016. Data penelitian yang cukup panjang yaitu selama periode 2011-2016 dapat dipandang cukup untuk menggambarkan kondisi Bank Syariah yang ada saat ini.

\subsection{Teknik Pengumpulan Data}

Data yang dikumpulkan dalam penelitian ini menggunakan teknik dokumentasi, yaitu teknik pengumpulan data dengan cara mengumpulkan berbagai data sekunder dari berbagai sumber. Data yang dikumpulkan dalam penelitian ini berupa laporan keuangan Bank Umum Syariah yang menjadi sampel penelitian, jurnal, dan sumber data lain yang relevan dan berkaitan dengan penelitian ini.

\subsection{Variabel Penelitian dan Pengukuran}

Penelitian ini akan menguji pengaruh tiga variabel independen terhadap satu variabel dependen. Kinerja keuangan bank syariah adalah variabel dependen yang diproksikan dengan Financing to Deposito Rasio (FDR), Non Performing Financing (NPF) dan Biaya Operasional Pendapatan Operasional (BOPO) sementara itu return bagi hasil deposito mudharabah sebagai variabel dependen.

\subsubsection{Variabel Dependen}

Variabel dependen merupakan variabel yang dipengaruhi oleh variabel yang lain (Sanusi, 2016, p. 50). Variabel dependen dalam penelitian ini adalah tingkat bagi hasil deposito Mudharabah pada Bank Umum Syariah yang diproyeksikan dengan rate of return bagi hasil deposito Mudharabah. Sekalipun terdapat berbagai faktor non-ekonomis yang sangat berpengaruh terhadap interaksi masyarakat dengan dunia perbankan, namun dalam keputusan memilih jasa perbankan tetap saja pertimbangan rasional (rational choice) sangat menentukan (Rivai et al., 2006). Menurut penelitian yang dilakukan oleh Isna dan Sunaryo (2012) tingkat bagi hasil merupakan salah satu faktor yang menjadi pertimbangan bagi nasabah dalam menginvestasikan dananya di perbankan syariah, untuk itu menjadi cukup penting bagi bank syariah untuk tetap menjaga kualitas tingkat bagi hasil yang diberikan kepada nasabahnya. Secara umum, formula perhitungan return bagi hasil dapat dirumuskan sebagai berikut:

$$
\text { Bagi hasil nasabah }=\frac{\text { Rata }- \text { rata dana nasabah }}{1000} \times H I-1000=\frac{\text { Nisbah nasabah }}{100}
$$

\subsubsection{Variabel Independen}

\section{Financing to Deposit Rasio (FDR)}

Menurut Rahmawaty dan Yudina (2015) salah satu ukuran liquid dari konsep persediaan adalah rasio pembiayaan terhadap deposit. Financing to Deposit Ratio (FDR) merupakan rasio total pembiayaan yang disalurkan ke nasabah pembiayaan dari sisi aktiva dibagi dengan jumlah dana masyarakat yang terkumpul dari sisi kewajiban. Sesuai dengan Surat Edaran Bank Indonesia No. 
Jurnal Ekonomi dan Perbankan Syariah

Vol. 6. No.1, April 2018: 63-89, ISSN (cet): 2355-1755 | ISSN (online): 2579-

6437

| 69

17/17/DKMP pada tanggal 26 Juni 2015, untuk menhitung rasio FDR menggunakan rumus sebagai berikut : (BI, 2015)

$$
F D R=\frac{\text { Total Pembiayaan Yang Diberikan }}{\text { Dana Pihak Ketiaa }(D P K)}=X 100 \%
$$

\section{Non Performing Financing (NPF)}

NPF terjadi ketika terdapat pinjaman yang memiliki kesulitan pelunasan, disebabkan oleh unsur kesengajaan dan bisa juga disebabkan oleh hal-hal diluar kendali yang belum dapat ditangani oleh peminjam (Arfiani \& Mulazid, 2017). Sesuai dengan Surat Edaran Bank Indonesia No. 17/19/DPUM pada tanggal 8 Juli 2015, untuk menhitung rasio NPF menggunakan rumus sebagai berikut : (BI, 2015)

$$
N P F=\frac{\text { Pembiayaan Bermasalah }}{\text { Total Pembiayaan }}=X 100 \%
$$

3. Biaya Operasional Pendapatan Operasional (BOPO)

BOPO merupakan variabel penting yang harus digunakan dalam mengukur profitabilitas perbankan, karena BOPO ini mengukur manajemen bank dalam menggunakan factor produksinya dengan efektif dan efisien (Asrina, 2015). Sesuai dengan Surat Edaran Bank Indonesia No 13/24/DPNP tanggal 25 Oktober 2011, untuk menhitung rasio BOPO menggunakan rumus sebagai berikut : (BI, 2011)

$$
B O P O=\frac{\text { Biaya Operasional }}{\text { Pendapatan Operasional }}=X 100 \%
$$

\subsection{Metode Analisis Data}

Data yang telah dikumpulkan selanjutnya akan dianalisis. Teknis analisis yang digunakan dalam penelitian ini adalah regeresi data panel. Regresi data panel yaitu regresi dengan menggabungkan data cross-section (data silang) dan time series (runtun waktu) dalam sebuah persamaan (Sriyana, 2014). Regresi ini dikembangkan untuk mengatasi berbagai masalah yang dihadapi saat melakukan regresi dengan cross-section dan time series.

Model persamaan regresi data panel menggabungkan data cross-section dan time series, persamaannya adalah sebagai berikut:

$$
\mathrm{Y}=\alpha+\beta_{1} X_{1 i t}+\beta_{2} X_{2 i t}+\beta_{3} X_{3 i t}+\varepsilon
$$


70 | Khairul Umuri: Faktor-Faktor Yang Mempengaruhi Return Bagi Hasil Deposito Mudharabah (Studi Empiris Pada Bank Umum Syariah di Indonesia Tahun 2012-2016)

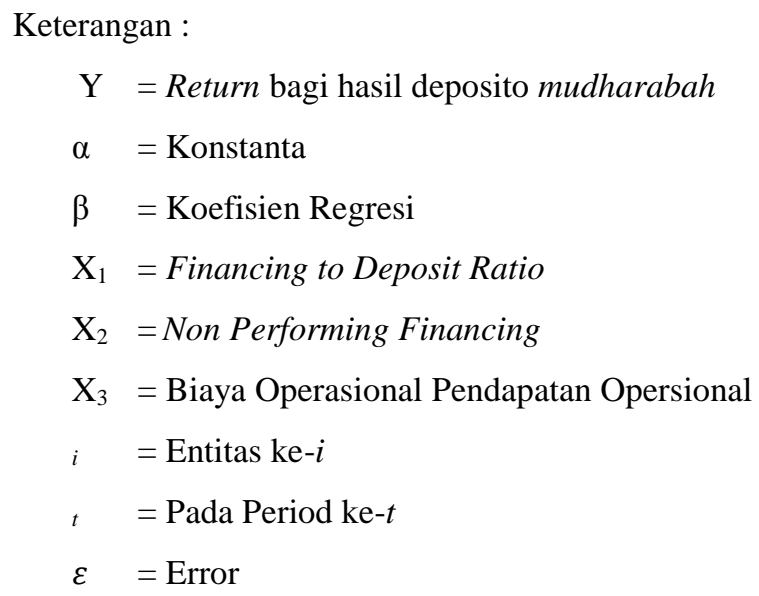

\section{ANALISIS DAN PEMBAHASAN}

4.1 Statistik Deskriptif

Tabel 1 Hasil Uji Analisis

\begin{tabular}{|l|c|c|c|c|}
\hline & FDR & NPF & BOPO & ROR \\
\hline Mean & 98.90467 & 5.428444 & 92.67778 & 5.985556 \\
\hline Median & 93.97000 & 3.300000 & 91.01000 & 5.760000 \\
\hline Maksimum & 197.7000 & 43.19000 & 192.6000 & 9.910000 \\
\hline Minimum & 79.19000 & 0.200000 & 47.60000 & 3.890000 \\
\hline Std. Dev & 21.84657 & 7.878382 & 23.30556 & 1.324379 \\
\hline Observations & 45 & 45 & 45 & 45 \\
\hline
\end{tabular}

Sumber : Output uji analisis deskriptif dengan Eviews 9

Financing to Deposit Ratio (FDR) memiliki rata-rata nilai $98.90 \%$ dan median sebesar 93.97\%. Nilai FDR ini cukup aman sesuai dengan Surat Edaran Bank Indonesia No 26/5/BPPP tanggal 29 Mei 1993 yang menyatakan batas rasio FDR Bank Syariah tidak boleh melebihi $110 \%$. Data Financing to Deposit Ratio (FDR) terendah (minimum) adalah 79.19, dan nilai tertinggi (maksimum) adalah 197.70\%. Nilai FDR terendah dimiliki oleh Bank Syariah Mandiri pada tahun 2016, dan nilai tertinggi dimiliki oleh Bank Panin Syariah pada tahun 2012. Sementara nilai simpangan baku (standar deviasi) sebesar $21.84 \%$.

Non Performing Financing (NPF) memiliki nilai rata-rata (mean) sebesar $5.42 \%$, median sebesar $3.30 \%$, nilai terendah (minimum) sebesar $0.20 \%$ serta nilai tertinggi (maksimum) sebesar 43.19\%. Nilai tertinggi sebesar $43.19 \%$ dialami oleh Maybank Syariah pada tahun 2016. NPF yang dialami oleh Maybank Syariah pada tahun 2016. Angka NPF tersebut tergolong pada predikat tidak sehat sesuai dengan Peraturan Bank Indonesia No. 6/10/PBI/2004 tentang Sistem Penilaian Tingkat Kesehatan Bank Umum dan Bank Syariah. Sementara itu nilai Non Performing 
Jurnal Ekonomi dan Perbankan Syariah

Vol. 6. No.1, April 2018: 63-89, ISSN (cet): 2355-1755 | ISSN (online): 2579-

6437

\section{| 71}

Financing terendah dialami oleh Bank Panin Syariah pada tahun 2012 dan tergolong pada prdikat sehat. Dari data tersebut dapat kita ketahui nilai mean dan nilai median tidak berbeda jauh, namun nilai maximum dan nilai minimum cukup berbeda jauh. Artinya data yang ada bersifat heterogen, namun nilai simpangan baku cukup kecil yaitu sebesar $7.87 \%$.

Biaya Operasional Pendapatan Operasional memiliki nilai rata-rata sebesar $92.67 \%$, median sebesar $91.01 \%$, nilai minimum $47.60 \%$, serta nilai maximum sebesar $192.60 \%$. Artinya rata-rata biaya operasional yang dikeluarkan untuk memperoleh pendapatan adalah sebesar $92.67 \%$ dengan nilai paling tinggi adalah sebesar $192.60 \%$ dan nilai terendah adalah $47.60 \%$. Sementara itu nilai simpangan baku (standar deviasi) adalah sebesar $22.30 \%$ menunjukkan simpangan baku yang relatif kecil karena lebih rendah dari nilai rata-rata.

\subsection{Pendekatan Model Regresi Data Panel}

\section{Hasil Uji Comment Effect Model}

Dependent Variable: Y

Method: Panel Least Squares

Date: 01/18/18 Time: 15:31

Sample: 20122016

Periods included: 5

Cross-sections included: 9

Total panel (balanced) observations: 45

\begin{tabular}{crrrr}
\hline \hline & $\begin{array}{r}\text { Coeffici } \\
\text { ent }\end{array}$ & Std. Error & t-Statistic & Prob. \\
\hline \hline Variable & 0.00651 & & & \\
& 0 & 0.011522 & 0.565064 & 0.5751 \\
& - & & & \\
X2 & 0.04516 & & & \\
& 6 & 0.060295 & -0.749096 & 0.4581 \\
X3 & 0.02322 & & & \\
& 7 & 0.020956 & 1.108362 & 0.2742 \\
$\mathrm{C}$ & 3.43416 & & & \\
& 1 & 2.478106 & 1.385800 & 0.1733
\end{tabular}


72 | Khairul Umuri: Faktor-Faktor Yang Mempengaruhi Return Bagi Hasil Deposito Mudharabah (Studi Empiris Pada Bank Imum Syariah di Indonesia Tahun 2012-2016)

\begin{tabular}{lrlr}
\hline \hline & 0.03646 & & 5.9855 \\
R-squared & 9 & Mean dependent var & 56 \\
& - & & \\
& 0.03403 & & \\
Adjusted R-squared & 3 & S.D. dependent var & 7.3243 \\
& 1.34672 & & 79 \\
S.E. of regression & 7 & Akaike info criterion & 3.5179 \\
& 74.3606 & & 19 \\
Sum squared resid & 2 & Schwarz criterion & 3.6785 \\
& - & & 11 \\
Log likelihood & 75.1531 & & 3.5777 \\
& 7 & Hannan-Quinn criter. & 86 \\
F-statistic & 0.51727 & & 0.5565 \\
& 2 & Durbin-Watson stat & 46 \\
Prob(F-statistic) & 0.67272 & & \\
& 5 & & \\
\hline \hline
\end{tabular}

Sumber : Output Uji Pemilihan model Menggunakan Eviews 9

\section{Hasil Uji Fixed Effect Model}

Dependent Variable: Y

Method: Panel Least Squares

Date: 01/18/18 Time: 15:31

Sample: 20122016

Periods included: 5

Cross-sections included: 9

Total panel (balanced) observations: 45

\begin{tabular}{crrrr}
\hline \hline Variable & $\begin{array}{r}\text { Coefficie } \\
\text { nt }\end{array}$ & Std. Error & t-Statistic & Prob. \\
\hline \hline X1 & 0.005784 & 0.015705 & 0.368252 & 0.7150 \\
& - & & & \\
X2 & 0.046647 & 0.042726 & -1.091756 & 0.2828
\end{tabular}


Jurnal Ekonomi dan Perbankan Syariah

Vol. 6. No.1, April 2018: 63-89, ISSN (cet): 2355-1755 | ISSN (online): 2579-

6437

| 73

$\begin{array}{cllll}\text { X3 } & 0.029395 & 0.014391 & 2.042554 & 0.0492 \\ \mathrm{C} & 2.942535 & 2.347695 & 1.253372 & 0.2189\end{array}$

Effects Specification

\begin{tabular}{lclr}
\hline \hline Cross-section fixed (dummy variables) & \\
\hline \hline & & & \\
R-squared & 0.708483 & Mean dependent var & 5.9855 \\
& & & 56 \\
Adjusted R-squared & 0.611310 & S.D. dependent var & 1.3243 \\
& & & 79 \\
S.E. of regression & 0.825684 & Akaike info criterion & 2.6779 \\
& & & 69 \\
Sum squared resid & 22.49789 & Schwarz criterion & 3.1597 \\
& & & 46 \\
Log likelihood & 48.25431 & Hannan-Quinn criter. & 71 \\
& & & 1.8721 \\
F-statistic & 7.290981 & Durbin-Watson stat & 64 \\
Prob(F-statistic) & 0.000004 & & \\
\hline \hline
\end{tabular}

Sumber : Output Uji Pemilihan model Menggunakan Eviews 9

\section{Hasil Random Effect Model}

Dependent Variable: Y

Method: Panel EGLS (Cross-section random effects)

Date: 01/18/18 Time: 15:34

Sample: 20122016

Periods included: 5

Cross-sections included: 9

Total panel (balanced) observations: 45

Swamy and Arora estimator of component variances 
74 | Khairul Umuri: Faktor-Faktor Yang Mempengaruhi Return Bagi Hasil Deposito Mudharabah (Studi Empiris Pada Bank Umum Syariah di Indonesia Tahun 2012-2016)

\begin{tabular}{crrrr} 
Variable & $\begin{array}{r}\text { Coefficie } \\
\text { nt }\end{array}$ & Std. Error & t-Statistic & Prob. \\
\hline \hline X1 & 0.005531 & 0.012476 & 0.443301 & 0.6599 \\
& - & & & \\
X2 & 0.046627 & 0.041390 & -1.126523 & 0.2665 \\
X3 & 0.028706 & 0.014162 & 2.027018 & 0.0492 \\
C & 3.031285 & 2.077777 & 1.458908 & 0.1522
\end{tabular}

Effects Specification

S.D. Rho

\begin{tabular}{lllr}
\hline \hline $\begin{array}{l}\text { Cross-section random } \\
\text { Idiosyncratic random }\end{array}$ & & 1.176972 & 0.6702 \\
& & 0.825684 & 0.3298 \\
\hline \hline & \multicolumn{2}{c}{ Weighted Statistics } & \\
\hline \hline & & & \\
R-squared & 0.146064 & Mean dependent var & 1.7917 \\
& & & 66 \\
Adjusted R-squared & 0.083581 & S.D. dependent var & 0.8509 \\
& & & 27 \\
S.E. of regression & 0.814591 & Sum squared resid & 27.205 \\
& & & 87 \\
F-statistic & 2.337653 & Durbin-Watson stat & 1.5421 \\
Prob(F-statistic) & 0.087674 & & 15 \\
& & & \\
\hline \hline
\end{tabular}

Unweighted Statistics

\begin{tabular}{lrrr}
\hline \hline & & & 5.9855 \\
R-squared & 0.028587 & Mean dependent var & 56 \\
& & & 0.5596 \\
Sum squared resid & 74.96892 & Durbin-Watson stat & 26 \\
\hline \hline
\end{tabular}

Sumber : Output Uji Pemilihan model Menggunakan Eviews 9 
Jurnal Ekonomi dan Perbankan Syariah

Vol. 6. No.l, April 2018: 63-89, ISSN (cet): 2355-1755 | ISSN (online): 2579-

6437

75

4.3 Hasil Pemilihan Model Teknis Estimasi Regresi Data Panel

Uji Statistik F (Uji Chow)

Redundant Fixed Effects Tests

Equation: Untitled

Test cross-section fixed effects

\begin{tabular}{lrrr}
\hline \hline Effects Test & Statistic & d.f. & Prob. \\
\hline \hline Cross-section F & 9.509060 & $(8,33)$ & 0.0000 \\
Cross-section Chi-square & 53.797729 & 8 & 0.0000 \\
\hline \hline
\end{tabular}

Sumber: Output uji Chow dengan Eviews 9

Dari tabel di atas dapat dilihat nilai probabilitas Cross-section $\mathrm{F}$ adalah $0.0000<0,05$. Dengan demikian dapat disimpulkan bahwa Fixed Effects Model (FEM) lebih tepat dibandingkan dengan Common Effect Model (CEM).

Hausmant Test (Uji Hausman)

Correlated Random Effects - Hausman Test

Equation: Untitled

stion random effects

\begin{tabular}{lcrr}
\hline \hline & $\begin{array}{c}\text { Chi-Sq. } \\
\text { Statistic }\end{array}$ & $\begin{array}{r}\text { Chi-Sq. } \\
\text { d.f. }\end{array}$ & Prob. \\
\hline \hline Cross-section random & 1.905687 & 3 & 0.5922 \\
\hline \hline
\end{tabular}

Sumber : Output Uji Hausman Menggunakan Eviews 9

Berdasarkan hasil pengujian, didapat nilai probabilitas Cross-section random adalah $0.5922>0.05$. Dengan demikian dapat disimpulkan bahwa model yang terbaik adalah Random Effect Model.

Langrangge Multiplier Test (Uji LM) 
76 | Khairul Umuri: Faktor-Faktor Yang Mempengaruhi Return Bagi Hasil Deposito Mudharabah (Studi Empiris Pada Bank Imum Syariah di Indonesia Tahun 2012-2016)

Lagrange Multiplier Tests for Random Effects

Null hypotheses: No effects

Alternative hypotheses: Two-sided (Breusch-Pagan) and one-sided

(all others) alternatives

\begin{tabular}{cccc}
\hline \hline Cross- & & Test Hypothesis & \\
& section & Time & Both \\
\hline \hline Breusch-Pagan & 33.50571 & 0.396732 & 33.90244 \\
& $(0.0000)$ & $(0.5288)$ & $(0.0000)$
\end{tabular}

Sumber: Output uji Random Effect Model dengan Eviews 9

Berdasarkan Hasil Pengujian Lagrange Multiplier, didapat nilai P-value sebesar $0.0000<0.05$. maka dapat disimpulkan bahwa setelah melakukan ketiga pengujian ini, model yang terbaik adalam menggunakan Random Effect Model (REM).

\subsection{Uji Hipotesis}

Dependent Variable: $\mathrm{Y}$

Method: Panel EGLS (Cross-section random effects)

Date: 01/18/18 Time: $15: 34$

Sample: 20122016

Periods included: 5

Cross-sections included: 9

Total panel (balanced) observations: 45

Swamy and Arora estimator of component variances

\begin{tabular}{crrrr}
\hline \hline & $\begin{array}{r}\text { Coefficie } \\
\text { nt }\end{array}$ & Std. Error & t-Statistic & Prob. \\
\hline \hline $\mathrm{X} 1$ & 0.005531 & 0.012476 & 0.443301 & 0.6599
\end{tabular}


Jurnal Ekonomi dan Perbankan Syariah

Vol. 6. No.1, April 2018: 63-89, ISSN (cet): 2355-1755 | ISSN (online): 2579-

6437

| 77

$\begin{array}{lrrrr}\text { X2 } & 0.046627 & 0.041390 & -1.126523 & 0.2665 \\ \text { X3 } & 0.028706 & 0.014162 & 2.027018 & 0.0492 \\ \mathrm{C} & 3.031285 & 2.077777 & 1.458908 & 0.1522\end{array}$

\begin{tabular}{llrr}
\hline \hline & \multicolumn{2}{c}{ Effects Specification } & \\
& & S.D. & \multicolumn{1}{c}{ Rho } \\
\hline \hline Cross-section random & & 1.176972 & 0.6702 \\
Idiosyncratic random & & 0.825684 & 0.3298 \\
& & & \\
\hline \hline & Weighted Statistics & \\
& & & 1.7917 \\
R-squared & 0.146064 & Mean dependent var & 66 \\
Adjusted R-squared & 0.083581 & S.D. dependent var & 0.8509 \\
& & & 27 \\
S.E. of regression & 0.814591 & Sum squared resid & 27.205 \\
& & & 87 \\
F-statistic & 2.337653 & Durbin-Watson stat & 1.5421 \\
Prob(F-statistic) & 0.087674 & & 15 \\
& & & \\
\hline \hline
\end{tabular}

Unweighted Statistics

5.9855

R-squared $\quad 0.028587 \quad$ Mean dependent var $\quad 56$

$\begin{array}{lll}\text { Sum squared resid } & 74.96892 \quad \text { Durbin-Watson stat } & 26\end{array}$

Sumber: Output uji Random Effect Model dengan Eviews 9

Berdasarkan pengujian regresi dengan menggunakan Random Effect Model diatas maka didapat persamaan regresinya sebagai berikut :

$\mathrm{Y}=3.434161 \mathrm{C}+0.006510 \mathrm{X} 1-0.045166 \mathrm{X} 2+0.023227 \mathrm{X} 3$ 
78 | Khairul Umuri: Faktor-Faktor Yang Mempengaruhi Return Bagi Hasil Deposito Mudharabah (Studi Empiris Pada Bank Umum Syariah di Indonesia Tahun 2012-2016)

Keterangan :

Y : Return Bagi Hasil Deposito Mudharabah

C : Konstanta

X1 : Financing to Deposit Ratio (FDR)

$\mathrm{X} 2$ : Non Performing Financing (NPF)

X3 : Biaya Operasional Pendapatan Operasional

Persamaan tersebut dapat diinterprestasikan bahwa jika Financing to Deposit Ratio (FDR) mengalami peningkatan sebesar 1\%, maka return bagi hasil deposito mudharbah akan naik sebesar $0.006 \%$. Jika Non Performing Financing (FDR) naik sebesar 1\%, maka pertumbuhan return bagi hasil deposito Mudharabah akan menurun sebesar 0.04\%. Sementara itu jika Biaya Operasional Pendapatan Operasional (BOPO) mengalami kenaikan sebesar 1\%, maka akan terjadi kenaikan return bagi hasil deposito Mudharabah sebesar $0.02 \%$. Nilai konstanta (intercept) sebesar 3.434161 bermakna bahwa jika variabel FDR, NPF, dan BOPO tetap atau tidak berubah, maka pertumbuhan return bagi hasil deposito Mudharabah akan mengalami kenaikan sebesar 3.43\%.

Tabel 2 Hasil Uji Koefesien Determinasi

\begin{tabular}{|l|r|}
\hline R-squared & $\mathbf{0 . 1 4 6 0 6 4}$ \\
\hline Adjusted R-squared & 0.083581 \\
\hline \multicolumn{2}{|r|}{ Sumber : Output Uji Koefisien Determinasi Menggunakan Eviews 9} \\
\hline
\end{tabular}

Nilai R-square pada tabel 4.11 yaitu 0.146064 menunjukan bahwa proporsi pengaruh variabel Financing to Deposit Ratio (FDR), Non Performing Financing (NPF), dan Biaya Operasional dan Pendapatan Operasional (BOPO) terhadap variabel Return bagi hasil deposito Mudharabah sebesar 14\%. Berarti bahwa variabel FDR, NPF dan BOPO memiliki pengaruh terhadap return bagi hasil deposito Mudharabah pada bank syariah sebesar $14 \%$ sedangkan sisanya $86 \%$ dipengaruhi oleh variabel lain yang tidak ada dalam regresi.

Tabel 3 Uji Pengaruh Simultan (F-Test)

\begin{tabular}{|c|c|}
\hline F-statistic & 2.337653 \\
\hline $\operatorname{Prob}(\mathbf{F}$-statistic) & 0.087674 \\
\hline
\end{tabular}

Berdasarkan hasil uji F pada tabel di atas, kita mendapatkan nilai Prob (Fstatistic) sebesar 0.087674, lebih besar dari 0.05. Artinya H0 diterima atau H1 ditolak. Maka dapat kiat simpulkan bahwa Financing to Deposit Ratio (FDR), Non Performing Financing (NPF), dan Biaya Operasional dan Pendapatan Operasional (BOPO) secara bersama-sama tidak mempunyai pengaruh yang signifikan terhadap return bagi hasil deposito mudharabah pada Bank Umum Syariah.

Tabel 4 Uji Signifikan Parameter Individual (t-Test) 
Jurnal Ekonomi dan Perbankan Syariah

Vol. 6. No.1, April 2018: 63-89, ISSN (cet): 2355-1755 | ISSN (online): 2579-

6437

| 79

\begin{tabular}{crrrr}
\hline \hline Variable & $\begin{array}{r}\text { Coefficie } \\
\mathrm{nt}\end{array}$ & Std. Error & t-Statistic & Prob. \\
\hline \hline X1 & 0.005531 & 0.012476 & 0.443301 & 0.6599 \\
& - & & & \\
X2 & 0.046627 & 0.041390 & -1.126523 & 0.2665 \\
X3 & 0.028706 & 0.014162 & 2.027018 & 0.0492 \\
C & 3.031285 & 2.077777 & 1.458908 & 0.1522
\end{tabular}

Sumber: Output hasil uji T dengan Eviews 9

Berdasarkan tabel di atas, nilai probabilitas t hitung dari variabel bebas Financing to Deposit Ratio FDR sebesar 0.6599 yang lebih besar dari 0.05 dengan nilai probabilitas 0.6599 sehingga $\mathrm{H} 0$ diterima dan $\mathrm{H} 1$ ditolak. Artinya variabel FDR tidak berpengaruh signifikan yang positif terhadap variabel terikat return bagi hasil. Sama halnya dengan variabel bebas Non Performing Financing (NPF) didapatkan nilai probabilitas t hitung sebesar 0.2665 lebih besar dari 0.05 dengan koefesien -0.046627 sehingga $\mathrm{H} 0$ diterima dan $\mathrm{H} 1$ ditolak. Artinya variabel NPF tidak memebrikan pengaruh signifikan yang negatif terhadap variabel terikat return bagi hasil.

Berbeda dengan nilai probabilitas $\mathrm{t}$ hitung dari variabel bebas Biaya Operasional Pendapatan Operasional (BOPO), didapatkan nilai probabilitas sebesar 0.0492 lebih kecil dari 0.05 dengan nilai koefesien 0.0492 sehingga $\mathrm{H} 0$ diterima dan $\mathrm{H} 1$ diterima. Artinya variabel BOPO bank umum syariah tidak memberikan pengaruh negatif yang signifikan terhadap variabel terikat return bagi hasil deposito Mudharabah Bank Umum Syariah. Berdasarkan hasil uji t, Biaya Operasional Pendapatan Operasional (BOPO) memberikan pengaruh yang signifikan terhadap return bagi hasil deposito Mudharabah, akan tetapi pengaruhnya adalah positif karena nilai koefesien regresi BOPO bernilai positif.

\subsection{Pengaruh Variabel Yang Diteliti Secara Simultan}

Berdasarkan hasil uji statistik f menunjukkan bahwasannya seluruh variabel yang diuji meliputi Financing to Deposit Ratio (FDR), Non Performing Financing (NPF), dan Biaya Operasoonal dan Pendapatan Operasional (BOPO) secara simultan mempunyai pengaruh yang tidak signifikan terhadap return bagi hasil deposito Mudharabah. Nilai $R$-squared sebesar 0.146064 atau $14 \%$ menunjukkan bahwa variabel dependen (return bagi hasil deposito Mudharabah) dapat dijelaskan oleh variabel independennya sebesar $14 \%$ atau dengan kata lain, Financing to Deposit Rataio (FDR), Non Performing Financing (NPF), dan Biaya Operasional dan Pendapatan Operasional (BOPO) memberikan pengaruh hanya sebesar $14 \%$ terhadap return bagi hasil deposito Mudharabah. Sedangkan sisanya 
80 | Khairul Umuri: Faktor-Faktor Yang Mempengaruhi Return Bagi Hasil Deposito Mudharabah (Studi Empiris Pada Bank Umum Syariah di Indonesia Tahun 2012-2016)

$86 \%(100 \%-14 \%)$ variabel independen dijelaskan oleh variabel-variabel lain yang tidak dijelaskan dalam penelitian ini.

\subsection{Pengaruh Variabel yang Diteliti Secara Parsial}

1. Pengaruh Financing to Deposit Ratio Terhadap Return Bagi Hasil Deposito Mudharabah Bank Umum Syariah

Pada penelitian ini, hipotesis pertama yang diajukan yaitu bahwa Financing to Deposit Ratio (FDR) berpengaruh positif signifikan terhadap tingkat (return) bagi hasil deposito Mudharabah bank umum syariah. Hasil analisis regresi menunjukkan bahwa variabel Financing to Deposit Ratio (FDR) dalam penelitian ini memiliki koefisien sebesar 0.005531 dengan nilai signifikansi lebih dari 0.05 yaitu 0.6599. Berdasarkan hasil tersebut dapat disimpulkan bahwa H0 diterima dan H1 ditolak yang bermakna bahwa Financing to Deposit Ratio (FDR) tidak mempunyai pengaruh positif yang signifikan terhadap return bagi hasil deposito Mudharabah.

2. Pengaruh Non Performing Financing Terhadap Return Bagi Hasil Deposito Mudharabah Bank Umum Syariah

Hipotesis kedua yang diajukan dalam penelitian ini adalah bahwa Non Performing Financing (NPF) berpengaruh negatif signifikan terhadap return bagi hasil deposito Mudharabah bank umum syariah. Hasil analisis regresi menunjukkan bahwa variabel Non Performing Financing (NPF) dalam penelitian ini memiliki koefesien sebesar -0.046627 dengan nilai signifikansi sebesar 0.2665. Berdasarkan hasil tersebut dapat disimpulkan bahwa Non Performing Financing (NPF) tidak memiliki pengaruh negatif yang signifikan terhadap return bagi hasil deposito Mudharabah bank umum syariah. Hal ini berarti dapat disimpulkan bahwa H0 diterima dan $\mathrm{H} 1$ ditolak.

3. Pengaruh Biaya Operasional Pendapatan Operasional Terhadap Return Bagi Hasil Deposito Mudharabah Bank Umum Syariah

Hipotesis ketiga dalam penelitian ini yaitu Biaya Operasional Pendapatan Operasional (BOPO) berpengaruh negatif signifikan terhadap return bagi hasil deposito Mudharabah pada Bank Umum Syariah. Hasil analisis regresi berganda menunjukkan nilai koefesien variabel Biaya Operasional Pendapatan Operasional sebesar 0.028706 dengan tingkat signifikansi lebih kecil dari 0.05 yaitu 0.0492 . berdaraskan hasil tersebut, dapat disimpulkan bahwa $\mathrm{H} 0$ diterima dan $\mathrm{H} 1$ ditolak yang berarti bahwa Biaya Operasional Pendapatan Operasional tidak memberikan pengaruh negatif yang signifikan terhadap tingkat bagi hasil deposito Mudharabah pada Bank Umum Syariah. Meskipun nilai signifikansinya lebih kecil dari 0.05, yang berarti variabel Biaya Operasional Pendapatan Operasional berpengaruh signifikan terhadap return bagi hasil deposito Mudharabah, namun pengaruhnya adalah positif bukan negatif.

\section{KESIMPULAN}

Penelitian ini bertujuan untuk menguji pengaruh rasio keuangan Bank Syariah yang diporsikan dengan Financing to Deposit Ratio (FDR), Non 
Jurnal Ekonomi dan Perbankan Syariah

Vol. 6. No.1, April 2018: 63-89, ISSN (cet): 2355-1755 | ISSN (online): 2579-

6437

| 81

Performing Financing (NPF) dan Biaya Operasioanl Pendapatan Operasional (BOPO) terhadap return bagi hasil deposito Mudharabah yang diporsikan oleh ekuivalen rate deposito 1 bulan pada Bank Umum Syariah. Metode analisis yang digunakan dalam penelitian ini adalah metode regresi data panel. Sampel yang digunakan adalah 9 Bank Umum Syariah yang dipilih berdasarkan teknik purposive sampling dengan periode penelitian dari tahun 2012 sampai dengan 2016.

Berdasarkan hasil pengujian serta analisis dan pembahasan. Secara ringkas hasil penelitian ini adalah sebagai berikut :

1. Variabel Financing to Deposit Ratio (FDR) secara parsial tidak berpengaruh signifikan terhadap return bagi hasil deposito Mudharabah. Hal ini dibuktikan dengan nilai koefisien sebesar 0.005531 serta tingkat signifikansi sebesar 0.6599, dimana tingkat signifikansinya lebih besar dari 0.05. Oleh karena itu dapat disimpulkan bahwa hipotesis $1(\mathrm{H} 1)$ yang mengatakan FDR berpengaruh positif signifikan terhadap return bagi hasil deposito Mudharabah ditolak.

2. Variabel Non Performing Financing (NPF) secara parsial tidak berpengaruh signifikan terhadap return bagi hasil deposito Mudharabah. Hal ini dibuktikan dengan nilai koefesien -0.046627 serta tingkat signifikansi sebesar 0.2665 , dimana tingkat signifikansinya lebih besar dari 0.05. Oleh karena itu dapat disimpulkan bahwa hipotesis 2 (H2) yang mengatakan NPF berpengaruh negatif signifikan terhadap return bagi hasil deposito Mudharabah ditolak

3. Variabel Biaya Operasional Pendapatan Operasional (BOPO) secara parsial berpengaruh positif signifikan terhadap return bagi hasil deposito Mudharabah. Hal ini dibuktikan dengan dengan nilai koefesien sebesar 0.028706 serta tingkat signifikansi sebesar 0.0492 dimana tingkat signifikansinya lebih kecil dari 0.05 . Hasil ini tidak sesuai dengan teori yang menyatakan bahwa jika rasio BOPO naik, maka return bagi hasil deposito Mudharabah pada Bank Umum Syariah akan turun. Oleh karena itu hipotesis 3 (H3) yang mengatakan BOPO berpengaruh negatif signifikan terhadap return bagi hasil deposito Mudharabah ditolak.

4. Ketiga variabel independen yaitu Financing to Deposit Ratio (FDR), Non Performing Financing (NPF), dan Biaya Operasional Pendapatan Operasional (BOPO) secara simultan tidak berpengaruh siginifikan terhadap return bagi hasil deposito Mudharabah Bank Umum Syariah. Hal ini dibuktikan dengan nilai Adjuster R-squared sebesar 0.083581 lebih besar dari 0.05. Sehingga dapat disimpulkan bahwa H0 diterima dan H1 ditolak.

\section{DAFTAR PUSTAKA}

Akbar, D. A. (2016). Inflasi, Gross Domestic Product (GDP), Capital Adequacy Ratio (CAR), dan Financing to Deposit Ratio (FDR) Terhadap Non 
82 | Khairul Umuri: Faktor-Faktor Yang Mempengaruhi Return Bagi Hasil Deposito Mudharabah (Studi Empiris Pada Bank Umum Syariah di Indonesia Tahun 2012-2016)

Performing Financing (NPF) Pada Bank Umum Syariah Di Indonesia. IEconomic, 2(2), 19-37.

Alamsyah, H. (2015). Perkembangan dan Prospek Perbankan Syariah Indonesia: tangan Dalam Menyongsong MEA 2015. Jakarta: Ikatan Ahli Ekonomi Islam.

Antonio, M. S. (2003). Bank syariah: Dari Teori ke Praktik (6th ed.). Jakarta: Gema Insani Press.

Arfiani, L. R., \& Mulazid, A. S. (2017). Analisis Faktor-faktor yang Mempengaruhi Tingkat Bagi Hasil Simpanan Mudharabah pada Bank Umum Syariah Indonesia Studi Kasus Pada Bank Umum Syariah di Indonesia Periode 2011-2015. Iqtishadia Jurnal Ekonomi Dan Perbankan Syariah, 4(1), 1-23.

Arif, M. (2011). The Effect of Macroeconomics Variable to The Profit-Sharing Yield Decision in Indonesia Islamic Banking Industry. Economic Journal of Emerging Markets, 3(3), 235-244.

Arif, M. N. A. Al. (2010). Dasar-dasar Manajemen Pemasaran Bank Syariah. Bandung: Alfabeta.

Asrina, P. (2015). Analisis Pengaruh PDB, Nilai Tukar Rupiah, Non Performing Financing (NPF), BOPO Terhadap Profitabilitas (ROA) Perbankan syariah di Indonesia Periode 2008-2013. Jom FEKON, 2(1), 1-13.

BI. Surat Edaran Bank Indonesia No.13/24/DPNP, Pub. L. No. 13 (2011). Republik Indonesia.

BI. Surat Edaran Bank Indonesia No. 17/17/DKMP (2015). Republik Indonesia.

BI. Surat Edaran Bank Indonesia No. 17/19/DPUM (2015). Republik Indonesia.

Dewan Syariah Nasional. (2006). Himpunan Fatwa Dewan Syariah Nasional MUI (4th ed.). Ciputat: Dewan Syari'ah Nasional Majelis Ulama Indonesia.

IFCI. (2016). Islamic Finance Country Index. Global Islamic Finance Report 2016.

Indonesia, R. Undang-Undang Republik Indonesia Nomor 21 Tahun 2008 Tentang Perbankan Syariah, Pub. L. No. 21 (2008). Republik Indonesia.

Ismail. (2010). Perbankan Syariah. Jakarta: Kencana Prenada Media Group.

Ismail. (2017). Manajemen Derbankan: Dari Teori Menuju Aplikasi (3rd ed.). Jakarta: Kencana Prenada Media Group.

Isna, A. K., \& Sunaryo, K. (2012). Analisis Pengaruh Return on Asset, Bopo, dan Suku Bunga Terhadap Tingkat Bagi Hasil Deposito Mudharabah Pada Bank Umum Syariah. Jurnal Ekonomi Dan Bisnis, 11(1), 29-42.

Karim, A. a, \& Affif, A. Z. (2006). Islamic Banking Consumer Behaviour in Indonesia: A Qualitative Approach. 7th International Conference on Islamic Economics., 1-19.

Natalia, E., Dzulkirom, M., \& Rahayu, S. M. (2014). Pengaruh Tingkat Bagi Hasil Deposito Bank Syariah dan Suku Bunga Deposito bank Umum Terhadap Jumlah Simpanan Deposito Mudharabah (Studi Pada PT. Bank Syariah Mandiri Periode 2009-2012). Jurnal Administrasi Bisnis, 9(1), 1-7.

Nofianti, N., Badina, T., \& Erlangga, A. (2015). Analisis Pengaruh Return on Asset (ROA), Biaya Operasional Terhadap Pendapatan Operasional (BOPO), Suku Bunga, Financing to Deposit Ratio (FDR) dan Non 
Jurnal Ekonomi dan Perbankan Syariah

Vol. 6. No.1, April 2018: 63-89, ISSN (cet): 2355-1755 | ISSN (online): 2579-

6437

| 83

Performing Financing (NPF) Terhadap Tingkat Bagi Hasil Deposito

Mudharabah (Studi Empiris pada Bank Umu. Jurnal Bisnis Dan Manajemen, 5(1), 65-86.

Novianto, A. S., \& Hadiwidjojo, D. (2013). Analisis Faktor-faktor yang Mempengaruhi Penghimpunan Deposito Mudharabah Perbankan Syariah di Indonesia. Jurnal Aplikasi Manajemen, 2(4), 595-604.

OJK. (2016). Statistik Perbankan Syariah 2016. Jakarta.

Rahayu, A. T., \& Pranowo, B. (2012). Analisis Pengaruh Tingkat Suku Bunga

Deposito Bank Konvensional Terhadap Deposito Mudharabah Pada Bank Syariah Di Indonesia. Jurnal Ekonomi Dan Studi Pembangunan, 4(1), 95106.

Rahayu, P. A., \& Bustaman. (2016). Pengaruh Return On Asset, Bopo Dan suku Bunga Terhadap Tingkat Bagi Hasil Deposito Mudharabah Bank Umum Syariah. Jurnal Ilmiah Mahasiswa Ekonomi Akuntansi (JIMEKA), 1(1), 143-149.

Rahmawaty, \& Yudina, T. A. (2015). Pengaruh Return On Asset ( ROA ) dan Financing To Deposit Ratio ( FDR ) terhadap Tingkat Bagi Hasil Deposito Mudharabah pada Bank Umum Syariah. JURNAL DINAMIKA AKUNTANSI DAN BISNIS, 2(1), 92-103.

Rivai, H. A., Lukviarman, N., Syafrizal, Lukman, S., Andrianus, F., \& Masrizal. (2006). Identifikasi Faktor Penentu Keputusan Konsumen Dalam Memilih Jasa Perbankan: Bank Syariah vs Bank konvensional. Kerjasama Bank Indonesia Dan Center for Banking Research (CBR) Universitas Andalas, 117.

Sanusi, A. (2014). Metode Penelitian Bisnis. Jakarta: Salemba Empat.

Sanusi, A. (2016). Metodologi Penelitian Bisnis. Jakarta: Salemba Empat.

Sriyana, J. (2014). Metode Regresi Data Panel. Yogyakarta: Ekonisia.

Syibly, M. R. (2008). The Need of Muslim Floating Market for Bank Syariah A Case Study of the Member of Pengajian Bisnis al-Kautsar NU in Special District of Yogyakarta. Jurnal Studi Agama, 8(1), 1-17.

Tjahjono, E. D., Ari, H. D., Yanuarti, T., Hermansyah, O., \& Savitri, M. (2009). Akar Krisis Ekonomi Global dan Dampaknya Terhadap Indonesia. Outlook Ekonomi Indonesia $2009 \quad 2014$. https://doi.org/10.20885/lariba.vol3.iss1.art1

Umiyati, \& Syarif, S. M. (2014). Kinerja Keuangan dan Tingkat Bagi Hasil Deposito Mudharabah Pada Bank Umum Syariah di Indonesia. Jurnal Akutansi Dan Keuangan Islam, 4(1), 45-66.

Wibowo, E. S., \& Syaichu, M. (2013). Analisis Pengaruh Suku Bunga, Inflasi, CAR, BOPO, NPF Terhadap Profitabilitas Bank Syariah. Diponegoro Journal of Management, 2(2), 1-10.

Yuliani. (2011). Hubungan Efisiensi Operasional Dengan Kinerja Profitabilitas Pada Sektor Perbankan Yang Go Publik Di Bursa Efek Jakarta. Jurnal Manajemen \& Bisnis Sriwijaya, 5(10), 89-97. 